\title{
Effects of pyruvate and glucose on the development of human preimplantation embryos in vitro
}

\author{
J. Conaghan ${ }^{1}$, A. H. Handyside ${ }^{1}$, R. M. L. Winston ${ }^{1}$ and \\ H. J. Leese ${ }^{2}$ \\ ${ }^{1}$ Institute of Obstetrics and Gynaecology, Royal Postgraduate Medical School, Hammersmith \\ Hospital, Du Cane Road, London W12 ONN, UK; and ${ }^{2}$ Department of Biology, University of York, \\ Heslington, York YO1 5DD, UK
}

\begin{abstract}
Although human embryos will develop in vitro for six days or more, little is known about the effects of the primary nutrients, pyruvate and glucose, on development. Because the nutrient requirements of embryos change thoughout preimplantation development, the effects of altering substrate concentrations in the culture medium were examined, using 'surplus' human preimplantation embryos cultured from the two-four-cell stage to the blastocyst stage in medium containing various concentrations of pyruvate and glucose. Between the one-cell stage and the two-four-cell stage all of the embryos were exposed to $0.47 \mathrm{mmol}$ pyruvate $1^{-1}$ and $5.5 \mathrm{mmol}$ glucose $1^{-1}$. Pyruvate as sole substrate in the medium could support blastocyst development to an extent of 59\% (10 of 17). Conversely, culture of embryos in pyruvate-free medium resulted in the developmental arrest of $84 \%$ (21 of 25 ) of embryos, and for the $16 \%$ (4 of 25 ) that did reach the blastocyst stage there was a significant decrease in metabolic activity on day 4-5, during the morula to blastocyst stage transition. Embryos could not use glucose to compensate for the lack of pyruvate in the medium. Pyruvate uptake was related to exogenous concentration and optimal development occurred at the highest concentration tested, $0.47 \mathrm{mmol} \mathrm{l}^{-1}$. Embryo development to the eight-cell stage was slightly enhanced $82 \%$ ( 14 of 17 ) versus $60 \%$ ( 24 of 40 ) when no glucose was added to the medium, and the resulting blastocysts had significantly more cells $(99.1 \pm 13.5$ versus $58.4 \pm 8.2 ; P<0.02$ ) than did embryos grown in the presence of $1 \mathrm{mmol}$ glucose $1^{-1}$. Specifically, embryos that had been grown in glucose-free medium had significantly more trophectoderm cells $(66.1 \pm 7.7$ versus $37.2 \pm 7.1, P=0.023)$ than did embryos cultured in 1 mmol glucose $1^{-1}$. At later stages, embryos could compensate for lack of glucose by increasing their pyruvate uptake. Glucose uptake was related to concentration in the medium only at the blastocyst stage and there was significant lactate production at all stages of development, even in the absence of glucose. These results provide important information for the formulation of culture media for human embryos. Pyruvate is an essential component of the medium, and omitting glucose at early cleavage stages helps to overcome the block to development at the four-eight-cell stage, and significantly increases the number of trophectoderm cells of the resulting blastocysts.
\end{abstract}

\section{Introduction}

Despite over a decade of human in vitro fertilization (IVF) and embryo transfer (ET), overall success rates remain disappointingly low and culture of human embryos from the one-cell to the blastocyst stage is at best only partially successful. Recent advances in superovulation protocols (Rutherford et al., 1988) and developments in culture media (Chatot et al., 1989) have failed to make a significant impact on human embryo development in culture or to improve human pregnancy rates after IVF.

The point of greatest failure after IVF, is the ET stage where the majority of embryos fail to implant after transfer. In

Received 23 September 1992. addition, embryos remaining after ET display poor rates of development in vitro, with only between $20 \%$ (Bolton et al., 1989) and $48 \%$ (Hardy, 1993) reaching the blastocyst stage. Much attention has therefore focused on the effects of modified culture media on embryo development (Chatot et al, 1990; Lawitts and Biggers, 1991; Fitzgerald and DiMattina, 1992) and the assessment of embryo quality (Plachot et al., 1986; Bolton et al., 1989; Conaghan et al., 1991). Embryo development can now be carefully assessed over a number of days by monitoring morphology, number of cells, metabolic turnover of substrates and allocation of cells to the trophectoderm and inner cell mass (ICM) at the later stages of preimplantation development.

Substrate utilization by embryos has been extensively studied in many species (Leese, 1991), including mice (Biggers, 
1971; Gardner and Leese, 1986), rats (Zhang and Armstrong, 1990; Brison and Leese, 1991), hamsters (McKiernan et al., 1991) and rabbits (Kane, 1987a; Robinson and Benos, 1991), as well as in domestic animals such as cows (Rieger ef al., 1992; Dorland et al., 1992), pigs (Petters et al., 1990), and sheep (Thompson et al., 1991, 1992). Some of these studies have been carried out on single embryos following the advent of ultramicrofluorometric techniques (Leese and Barton, 1984). Metabolic studies on human embryos have clearly demonstrated that nutrient uptake is related to viability (Hardy et al., 1989a). These findings not only suggest that new tests of embryo viability could be devised based on embryo metabolism, but, more importantly, that the culture media could be modified to suit the specific requirements of human embryos and thus provide a better environment for growth and development.

Nutrients are supplied in embryo culture media mainly at concentrations that are well above those present in vivo, on the basis of measurements of human plasma, follicular (Leese and Lenton, 1990) and hydrosalpinx (Gott et al., 1990a) fluids. The provision of excessive amounts of substrates, which are markedly different from concentrations in vivo, may be detrimental to embryo health and could produce erratic or abnormal patterns of development. The role of endogenous energy supplies is also unknown, but could be significant (Leese et al., 1993), and the relative contributions of exogenous and endogenous nutrients to the energy needs of early embryos is poorly understood. Rabbit embryos, for example, can develop for several days without exogenous nutrients (Kane, 1987b), but similar studies on human embryos have not been carried out. It has also been shown that mouse embryos consume only small quantities of glucose at the earliest stages of preimplantation development (Gardner and Leese, 1986), and that by using a modified medium, which omits glucose during early cleavage stages, 48 (Chatot et al., 1989) to $51 \%$ (Brown and Whittingham, 1992) of embryos, which would normally have blocked at the two-cell stage, can develop to the blastocyst stage. Glucose has also been shown to inhibit development in embryos of other species, including rats (DeHertogh et al., 1991; Reed et al., 1992), hamsters (Schini and Bavister, 1988; Seshagiri and Bavister, 1989) and sheep (Thompson et al., 1992). Conversely, glucose did not affect the number of swine embryos developing to the blastocyst stage (Hagen et al., 1991).

In the present study, the effect on human embryo development and metabolism of reduced concentrations or total removal of pyruvate or glucose from the culture medium has been assessed. Embryo development was assessed morphologically and by number of cells; metabolism was assessed by the uptake of pyruvate and glucose and the formation of lactate. The work has been carried out on surplus human embryos cultured from the two-four-cell stage, to the blastocyst stage of development in vitro.

\section{Materials and Methods}

\section{Source of human embryos}

The surplus human embryos used in this study were obtained from patients undergoing IVF at the Royal Postgraduate
Medical School, Hammersmith Hospital, London. Ethical permission for the study was granted by the Human Fertilization and Embryology Authority for Human IVF, the ethics committees of the collaborating institutions and the patients concerned.

The superovulation procedure has been described by Hillier et al. (1985) and Rutherford et al. (1988). Patients underwent pituitary desensitization with an LHRH agonist (Buserelin: Hoechst, Hounslow), before superovulation with human menopausal gonadotrophin (hMG; Pergonal: Serono, Welwyn Garden City). hCG, 10000 iu (Profasi: Serono) was administered when a minimum of three follicles had attained a mean diameter of $17 \mathrm{~mm}$ and serum oestradiol concentrations were greater than $3500 \mathrm{pmol} \mathrm{l}^{-1}$. Oocyte retrieval was performed $34-36 \mathrm{~h}$ later (day 0).

Handling of gametes was as described by Hillier et al. (1984). Oocytes were cultured in $1 \mathrm{ml}$ Earle's balanced salt solution (GIBCO BRL, Life Technologies Ltd, Middlesex) supplemented with $25 \mathrm{mmol}$ sodium bicarbonate $\mathrm{I}^{-1}$ (BDH Chemicals Ltd, Dorset), $0.47 \mathrm{mmol}$ pyruvate $\mathrm{l}^{-1}$ (Sigma Chemical Co., Dorset), antibiotics (Sigma) and 10\% v/v heat-inactivated maternal serum in a closed system gassed with $5 \%$ oxygen, $5 \%$ carbon dioxide and $90 \%$ nitrogen, at $37^{\circ} \mathrm{C}$. Glucose was present at a concentration of $5.55 \mathrm{mmol} \mathrm{I}^{-1}$ in this medium. After preincubation for $4-8 \mathrm{~h}$, the oocytes were inseminated, and they were checked for fertilization $16-18 \mathrm{~h}$ later (day 1). Normal fertilization was confirmed when two clear pronuclei could be seen in the oocyte cytoplasm.

\section{Embryo grade and number of cells}

On the morning of day 2 (40-42 h after insemination), embryos were examined for the number of cells and graded according to the shape and evenness of size of blastomeres and the degree of extracellular fragmentation. Embryos were observed under a zoom stereomicroscope (model SZH-ILLB: Olympus Optical Co. Ltd, Japan), at a magnification of $\times 128$, illuminated using a $6 \mathrm{~V}, 20 \mathrm{~W}$ halogen bulb. The method of grading was based on the system devised by Dawson et al. (1987), which is similar to those used by Plachot et al. (1986) and Scott et al. (1991).

\section{Embryo transfer}

Later the same morning (day $2 ; 42-44 \mathrm{~h}$ after insemination) up to three embryos were selected, on the basis of grade and rate of development, for transfer back to the patient. Embryos remaining after transfer were allocated to one of two experiments.

\section{Experimental design}

Earle's medium (as described above but with $10 \% \mathrm{v} / \mathrm{v}$ human serum albumin (HSA; Albuminar 20: Armour Pharmaceuticals, UK) instead of maternal serum, and with $1 \mathrm{mmol}$ instead of $5.55 \mathrm{mmol}$ glucose $\mathrm{I}^{-1}$ ) was used as control medium for the experiments. In the first experiment, the embryos from each individual patient were allocated in equal numbers to medium containing $0.47 \mathrm{mmol}$ pyruvate $\mathrm{l}^{-1}$ (control medium), or 
$0.23 \mathrm{mmol}$ or $0.0 \mathrm{mmol}$ pyruvate $\mathrm{l}^{-1}$. Glucose was unaltered in each case at $1 \mathrm{mmol}^{-1}$.

In the second experiment, the embryos from individual patients were allocated in equal numbers to medium containing $1 \mathrm{mmol}$ glucose $\mathrm{l}^{-1}$ (control medium), or $0.5 \mathrm{mmol}$ or $0.0 \mathrm{mmol}$ glucose $1^{-1}$. Pyruvate concentration was unchanged at $0.47 \mathrm{mmol} \mathrm{l}^{-1}$ throughout.

The Earle's medium contained no lactate, which, with a low background glucose concentration of $1 \mathrm{mmol} \mathrm{l}^{-1}$, greatly facilitated measurement of substrates during these experiments. All cultures were carried out in a gas phase of $5 \% \mathrm{CO}_{2}$ in air at $37^{\circ} \mathrm{C}$.

\section{Incubation of embryos}

Normally fertilized embryos at the two-four-cell stage (42-44 h after insemination) were denuded of all remaining cumulus cells by gentle manipulation using a series of finely drawn Pasteur pipettes. The procedure for incubating the embryos in drops was similar to that described by Hardy et al. (1989a). Embryos were washed in three changes of the approriate medium (see above) and placed individually in a $5 \mu \mathrm{l}$ drop of similar medium under filter-sterilized silicone fluid (Dow Corning 200/50 cs; BDH). Similar drops of medium incubated adjacent to the embryo-containing drops served as controls. After incubation overnight (day 3), embryos were removed from their drops and again washed three times into fresh drops of the same medium. This procedure was repeated daily, for 4 days, until the morning of day 6 ( $135 \mathrm{~h}$ after insemination), at which point culture was terminated and the number of cells of the embryo determined using differential fluorescence labelling of nuclei (Hardy et al., 1989b). The spent medium from each individual drop was assayed to determine the depletion of pyruvate and glucose and the appearance of lactate.

\section{Fluorescence assays}

The concentrations of pyruvate, glucose and lactate in the control and incubation drops were determined by modifications of the methods of Leese and Barton (1984), Gardner and Leese (1986) and Hardy et al. (1989a). The reagents were prepared as shown below and assays conducted using a CobasBio Autoanalyser (Roche Products, Welwyn Garden City). The programmes used to perform the assays were based on those described by Harrison et al. (1988) and Stappenbeck et al. (1990). All of the assays are fluorometric and based on standard methods of enzymatic analysis in which the pyridine nucleotides NADH or NADPH are generated or consumed in coupled reactions. When $\mathrm{NADH}$ is excited at $340 \mathrm{~nm}$ it emits fluorescence at $459 \mathrm{~nm}$ and above. The amount of fluorescence emitted is proportional to the amount of $\mathrm{NAD}(\mathrm{P}) \mathrm{H}$ in the cuvette. As the consumption or generation of $\mathrm{NAD}(\mathrm{P}) \mathrm{H}$ is directly coupled to the consumption or depletion of substrate in the sample, it is possible, by comparison with standard curves, to calculate the concentration of substrate in the medium and, therefore, the amount taken up or produced by the embryo.

After embryo culture, duplicate $2 \mu$ l samples were recovered from the incubation and control drops. One sample was diluted in $398 \mu \mathrm{l}$ double-distilled water and assayed for pyruvate and glucose content. The second $2 \mu$ l sample was diluted in $118 \mu l$ of $5 \mu \mathrm{mol}$ lactate $\mathrm{l}^{-1}$ standard solution and analysed for lactate content. All chemicals used were obtained from Boehringer Mannheim (East Sussex) unless otherwise stated.

\section{Pyruvate assay}

Diluted medium, $60 \mu \mathrm{l}$, was sampled automatically and added to $200 \mu \mathrm{l} 50 \mathrm{mmol}$ phosphate buffer $\mathrm{l}^{-1}(30 \mathrm{mmol}$ $\mathrm{K}_{2} \mathrm{HPO}_{4} \mathrm{l}^{-1}(\mathrm{BDH})$ and $\left.20 \mathrm{mmol} \mathrm{NaH} \mathrm{PO}_{4} \mathrm{l}^{-1}(\mathrm{BDH})\right)(\mathrm{pH}$ 7.0), containing $5 \mu \mathrm{mol} \mathrm{NADH} \mathrm{l^{-1 }}$. Enzyme solution, $10 \mu \mathrm{l}$ ( $50 \mu \mathrm{l}$ of $\mathrm{LDH}\left(300 \mathrm{iu} \mathrm{mg}^{-1}\right.$ ) added to $4 \mathrm{ml}$ distilled water) was then added automatically and the conversion of $\mathrm{NADH}$ to NAD was compared with pyruvate standards in the range of $2-6 \mu \mathrm{mol} \mathrm{l}^{-1}$.

\section{Glucose assay}

Diluted medium, $70 \mu \mathrm{l}$, was sampled automatically and added to $200 \mu \mathrm{l}$ of Tris buffer $\left(24 \mathrm{ml}\right.$ of $0.1 \mathrm{~mol}$ Tris buffer $\mathrm{1}^{-1}$ (Sigma) ( $\mathrm{pH} 8.0$ ) added to $4.8 \mathrm{ml}$ of $0.1 \mathrm{~mol} \mathrm{MgCl} \mathrm{l}^{-1}(\mathrm{BDH})$ and $0.5 \mathrm{ml}$ of NADP/ATP mixture made using three parts of $3 \mathrm{mmol} \mathrm{NADP}^{-1}$ to two parts of $10 \mathrm{mmol} \mathrm{ATP} \mathrm{l}^{-1}$ ). Enzyme solution, $40 \mu \mathrm{l}$, (50 $\mathrm{ll}$ of hexokinase/glucose-6-phosphate dehydrogenase $\left(3.2 \mathrm{~mol}^{-1}\right)$ added to $4 \mathrm{ml}$ of distilled water), was added before assay. Glucose solutions $\left(2,4\right.$ and $\left.6 \mu \mathrm{mol} \mathrm{I}^{-1}\right)$ were used as standards. The programme used was a modification of that described by Stappenbeck ef al. (1990), in that five readings were taken, one every $30 \mathrm{~s}$, with the emission filter and excitation wavelength as described for their pyruvate assay.

\section{Lactate assay}

Diluted medium, $40 \mu \mathrm{l}$, was sampled automatically and added to $200 \mu \mathrm{l}$ buffer $\left(6.7 \mathrm{ml}\right.$ of solution $\mathrm{A}$ ( $2 \mathrm{~mol}$ glycine $\mathrm{l}^{-1}$ (Sigma), $0.8 \mathrm{~mol}$ hydrazine sulfate $\mathrm{l}^{-1}$ (Sigma) and $10 \mathrm{mmol}^{-1}$ EDTA $(\mathrm{BDH}))$ added to $6.7 \mathrm{ml}$ of $2 \mathrm{~mol} \mathrm{NaOH} \mathrm{l}{ }^{-1}, 11 \mathrm{ml}$ of doubledistilled water and $0.6 \mathrm{ml}$ of $\left.25 \mathrm{mmol} \mathrm{NAD} \mathrm{l}^{-1}\right)$. After preincubation for $5 \mathrm{~min}, 20 \mu \mathrm{l}$ of enzyme solution $(400 \mu \mathrm{l}$ of LDH ( 300 iu $\mathrm{mg}^{-1}$ ) added to $4 \mathrm{ml}$ of distilled water) was added. The generation of NADH was related to 5, 10 and $15 \mu$ mol lactate $1^{-1}$ standards. Readings were taken every $30 \mathrm{~s}$ for $20 \mathrm{~min}$, using an emission filter and excitation wavelength as described by Stappenbeck et al. (1990) for their pyruvate assay.

\section{Double labelling of blastocysts to determine the numbers of trophectoderm and inner cell mass cells}

Embryos were labelled using the technique of Hardy et al. (1989b), which is based on that of Handyside and Hunter (1984, 1986). Embryo zonae were removed in acid Tyrode's solution, $\mathrm{pH} 2.4$, and allowed to recover for $10 \mathrm{~min}$ in Earle's medium, supplemented with 20.85 mmol Hepes $1^{-1}$ (Calbiochem, Behring Diagnostics, La Jolla), $4 \mathrm{mmol}$ sodium bicarbonate $^{-1}$, antibiotics and $10 \% \mathrm{v} / \mathrm{v}$ HSA (Earle's handling medium; EHM). The embryos were incubated on ice for $10-15 \mathrm{~min}$ in $10 \mathrm{mmol}$ trinitrobenzensulfonic acid $\mathrm{l}^{-1}$ (Sigma) containing $4 \mathrm{mg}$ polyvinylpyrolidone $\mathrm{ml}^{-1}$ (Calbiochem) in EHM. After washing three times in EHM, embryos were placed for $10 \mathrm{~min}$ at $37^{\circ} \mathrm{C}$ in $0.1 \mathrm{mg}$ anti-DNP-BSA ml ${ }^{-1}$ (ICN ImmunoBiologicals, High 
Table 1. Development of surplus human embryos from day 2 to day 6 in media containing various concentrations of pyruvate or glucose

Treatment

\begin{tabular}{|c|c|c|c|c|c|}
\hline $\begin{array}{l}\text { Pyruvate } \\
\left(\mathrm{mmol} \mathrm{l}^{-1}\right)\end{array}$ & $\begin{array}{c}\text { Glucose } \\
\left(\mathrm{mmol} \mathrm{L}^{-1}\right)\end{array}$ & $\begin{array}{l}\text { Number of } \\
\text { embryos }\end{array}$ & $\begin{array}{l}\text { Number reaching the } \\
\text { eight-cell stage } \\
(\%)\end{array}$ & $\begin{array}{l}\text { Number reaching the } \\
\text { morula stage } \\
(\%)\end{array}$ & $\begin{array}{c}\text { Number reaching the } \\
\text { blastocyst stage } \\
(\%)\end{array}$ \\
\hline 0.00 & 1.00 & 25 & $13(52)$ & $7(28)$ & $4(16)^{a}$ \\
\hline 0.23 & 1.00 & 24 & $10(42)$ & $9(38)$ & $8(33)$ \\
\hline 0.47 & 1.00 & 40 & $24(60)$ & $22(55)$ & $19(48)$ \\
\hline 0.47 & 0.50 & 16 & $13(81)$ & $12(75)$ & $10(63)$ \\
\hline 0.47 & 0.00 & 17 & $14(82)$ & $13(76)$ & $10(59)$ \\
\hline
\end{tabular}

Figures in italics represent control medium.

${ }^{2}$ The total number of embryos and the number of eight-cell embryos reaching the blastocyst stage is significantly lower than in the control group $(P<0.02)$.

Wycombe). After another three washes in EHM, the embryos were incubated for $15-30 \mathrm{~min}$ at $37^{\circ} \mathrm{C}$ in EHM supplemented with $0.01 \mathrm{mg}$ propidium iodide $\mathrm{ml}^{-1}$ (Sigma) and $10 \% \mathrm{v} / \mathrm{v}$ guinea-pig complement serum (Sigma). After $15 \mathrm{~min}$ they were carefully observed until even lysis of the outer trophectoderm cells was seen, and they were then quickly transferred into 0.05 mmol bisbenzimide $\mathrm{l}^{-1}$ (Hoechst 33258, Sigma) in absolute alcohol. After overnight storage at $4^{\circ} \mathrm{C}$, the embryos were washed in absolute alcohol for at least $30 \mathrm{~min}$, and mounted in glycerol under a coverslip on a microscope slide.

Labelled nuclei were observed under a Leitz Laborlux D microscope (Leica UK) with $\lambda$ Ploemopak incident-light fluorescence illuminator (Leica), incorporating a filter set made up of a UV excitation and band pass filter (A2; Leica) and an emission filter from a FITC filter set (I2; Leica). With this combination of filters, trophectoderm nuclei labelled with propidium iodide and bisbenzimide appear orange, and ICM nuclei labelled with bisbenzimide appear green. After examining in whole mount for the degree and evenness of labelling, the embryo was disaggregated by applying gentle pressure on the coverslip with a pencil eraser. Trophectoderm and ICM nuclei were counted. The number of dead cells was recorded but not included in the overall number of cells.

\section{Statistical analysis}

Mean substrate uptake and production was expressed as pmol per embryo $h^{-1} \pm$ SEM. Differences between groups were compared using the Wilcoxon Rank-Sum (Mann-Whitney) test. Differences in the number of embryos developing to the blastocyst stage, and number of cells between different groups were compared using $\chi^{2}$ with continuity correction. All statistical analyses were perfomed using STAT VIEW II (Abacus Concepts Inc., Berkeley, CA).

\section{Results}

\section{Development of preimplantation embryos}

The development of 122 surplus embryos, from 22 patients, in a variety of media is shown (Table 1). As no differences were observed for embryos cultured in control medium $(0.47 \mathrm{mmol}$ pyruvate $\mathrm{I}^{-1}$ and $1 \mathrm{mmol}$ glucose $\mathrm{I}^{-1}$ ) between the experiments with altered pyruvate and altered glucose concentrations, the data were amalgamated. The serum supplement (HSA) used in these experiments contained a small amount of pyruvate and glucose. Thus, medium to which substrate had not been added was found to contain background concentrations of $0.06 \mathrm{mmol}$ glucose $1^{-1}$ and $0.09 \mathrm{mmol}$ pyruvate $1^{-1}$ and as a result, embryos cultured in medium to which pyruvate or glucose had not been added, showed slight uptake.

\section{Effect of changing the pyruvate concentration in the culture medium}

Lowering the pyruvate concentration from $0.47 \mathrm{mmol} \mathrm{l}^{-1}$ to $0.23 \mathrm{mmol} \mathrm{I}^{-1}$ did not significantly reduce the percentage of embryos reaching the blastocyst stage (48\% (19 of 40 ) to $33 \%$ ( 8 of 24) $P=0.3$, (Table 1 )), and had no major effect on number of cells $(67.7 \pm 11.9$ in medium with reduced pyruvate and $58.4 \pm 8.2$ in control medium, $P=0.4$ ) (Fig. 1). By removing the pyruvate completely, significantly fewer embryos reached the blastocyst stage $(16 \% ; 4$ of $25, P<0.02)$, and the resulting blastocysts were observed to be extremely fragile (two out of four blastocysts disintegrated completely as soon as they were exposed to the acid Tyrode's during the labelling procedure). For the two blastocysts that were successfully labelled, the number of cells was found to be similar to controls, with 47 and 58 cells, compared with $58.4 \pm 8.2$ (range $21-145$ ) in the control group (Fig. 1).

The pyruvate uptake by embryos doubled in line with its concentration in the medium and these differences in uptake were mostly significant (see Fig. 2a). Glucose uptake was virtually unchanged at all pyruvate concentrations and at all stages of development, apart from day 4-5, when it fell significantly from $20 \pm 2.6$ pmol per embryo $\mathrm{h}^{-1}$ (range $1.2-44.2$ ) in control medium to $10 \pm 2.4$ pmol per embryo $h^{-1}$ (range 6.44-17) in pyruvate-free medium ( $P=0.03$, Fig. 2b). However, this reduction in uptake was not sustained, and embryos made a full recovery, displaying no differences in uptake over the final day of culture. Coupled with the fall in glucose uptake was a significant fall in lactate production $(22.7 \pm 6.2$ pmol per embryo $h^{-1}$ (range 14.5-41.0) in pyruvate-free medium and 

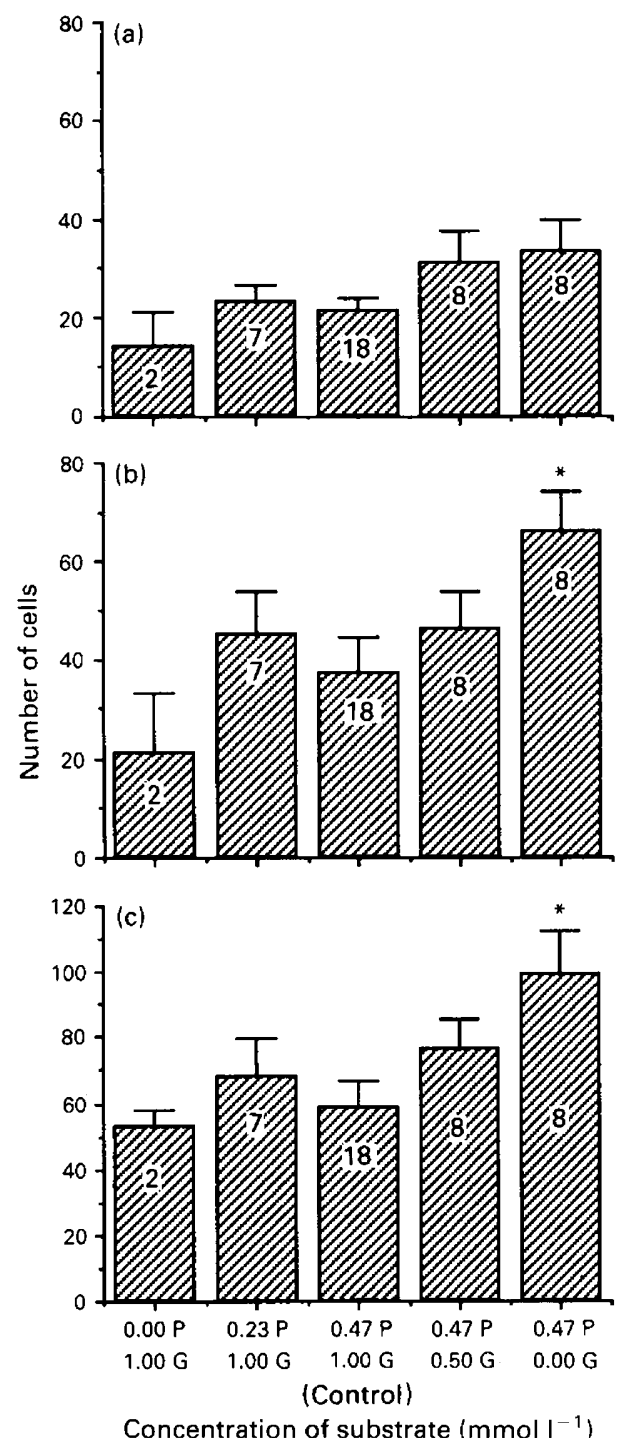

Fig. 1. Number of cells for embryos that developed to the blastocyst stage in media containing various concentrations of pyruvate $(P)$ or glucose $(G)$. (a) Number of inner cell mass cells ( \pm SEM); (b) number of trophectoderm cells ( \pm SEM); and (c) total number of cells ( \pm SEM). The number of embryos successfully labelled and counted in each group is shown within the bars. "Significantly higher than control value $(P<0.05)$.

$38.4 \pm 2.9$ pmol per embryo $\mathrm{h}^{-1}$ (range $\left.0-31.7\right)$ in $0.47 \mathrm{mmol}$ pyruvate $\mathrm{I}^{-1}, P=0.023$ ) on day $4-5$ of development (Fig. 2c).

\section{Effect of changing the glucose concentration in the culture medium}

Although the number of embryos reaching the blastocyst stage was not significantly different in any of the glucose concentrations examined (Table 1 ), the number of blastocyst cells increased as glucose was reduced: $58.4 \pm 8.2$ (range 21-145), $76.4 \pm 9.9$ (range 35-108), and 99.1 \pm 13.5 (range 43-136) in $1 \mathrm{mmol}, 0.5 \mathrm{mmol}$ and $0.0 \mathrm{mmol}$ glucose $\mathrm{l}^{-1}$, respectively. Differences in number of cells between control $\left(1 \mathrm{mmol} \mathrm{l^{-1 }}\right)$ and glucose-free medium were statistically significant, $P=0.016$. Trophectoderm cells were most affected by lack of glucose,

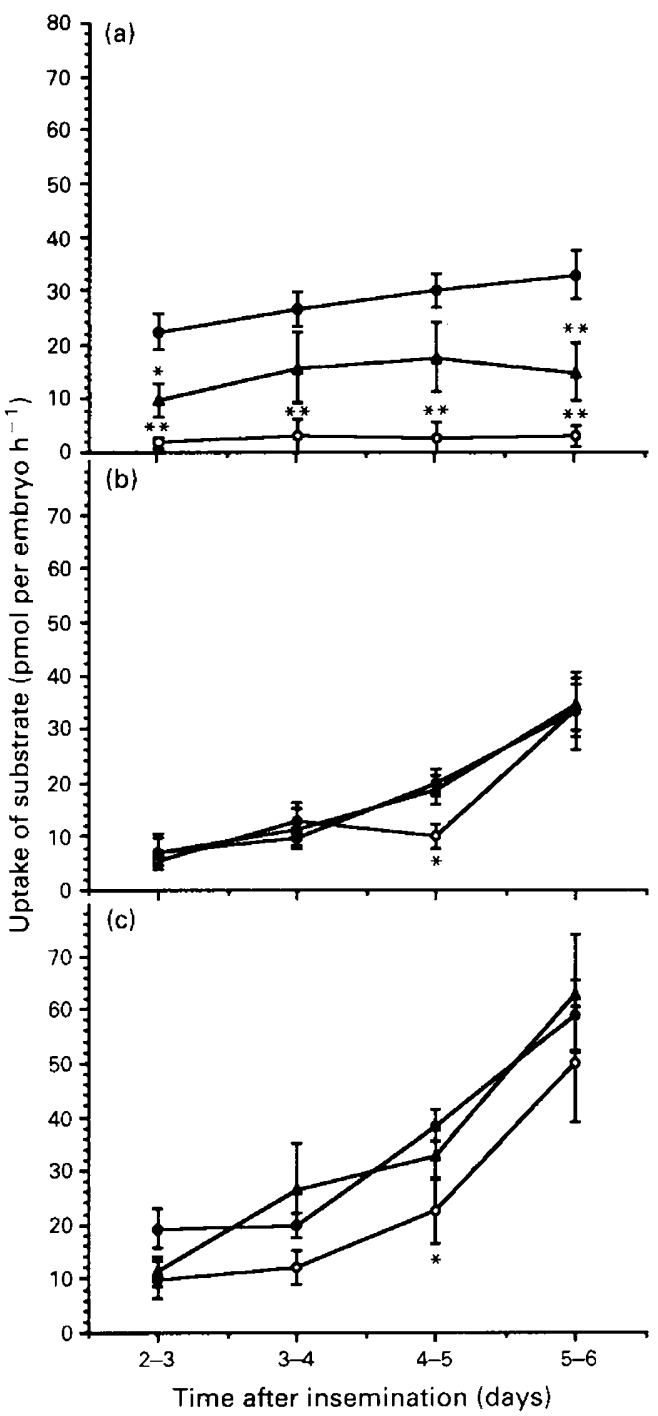

Fig. 2. Uptake of (a) pyruvate, (b) glucose and (c) production of lactate by embryos that reached blastocyst stage in medium supplemented with (O) $0.00 \mathrm{mmol},(\boldsymbol{\Delta}) 0.23 \mathrm{mmol}$ and (O) $0.47 \mathrm{mmol}$ (control) pyruvate $\mathrm{I}^{-1}$. Glucose $\left(1 \mathrm{mmol} \mathrm{l}^{-1}\right)$ was present throughout. Values are means \pm SEM. Significantly lower than control value $\left({ }^{*} P<0.05\right.$ $\left.{ }^{* *} P<0.01\right)$.

their numbers increasing from $37.2 \pm 7.1$ (range 6-109) in control medium to $66.1 \pm 7.7$ (range $40-91$ ) in glucose-free medium, $P=0.023$ (Fig. 1). The number of ICM cells increased from $21.2 \pm 2.8$ (range $7-53$ ) to $33.0 \pm 6.8$ (range 2-59) in $1.0 \mathrm{mmol} \mathrm{l}^{-1}$ (control medium) and $0 \mathrm{mmol}$ glucose $\mathrm{l}^{-1}$, respectively, but this difference was not significant.

Differences in pyruvate uptake in the various glucose concentrations were small, except on day $4-5$ when the embryos consumed significantly more pyruvate $(P=0.02)$ in the absence of glucose, compared with controls (Fig. 3a). Glucose uptake by embryos cultured in the various glucose concentrations was similar at the beginning of culture but by day 5-6 was related to the concentration of glucose in the culture medium (Fig. 3b). Lactate production was similar in the $1 \mathrm{mmol}$, $0.5 \mathrm{mmol}$ and $0.0 \mathrm{mmol}$ glucose $1^{-1}$ concentrations during 


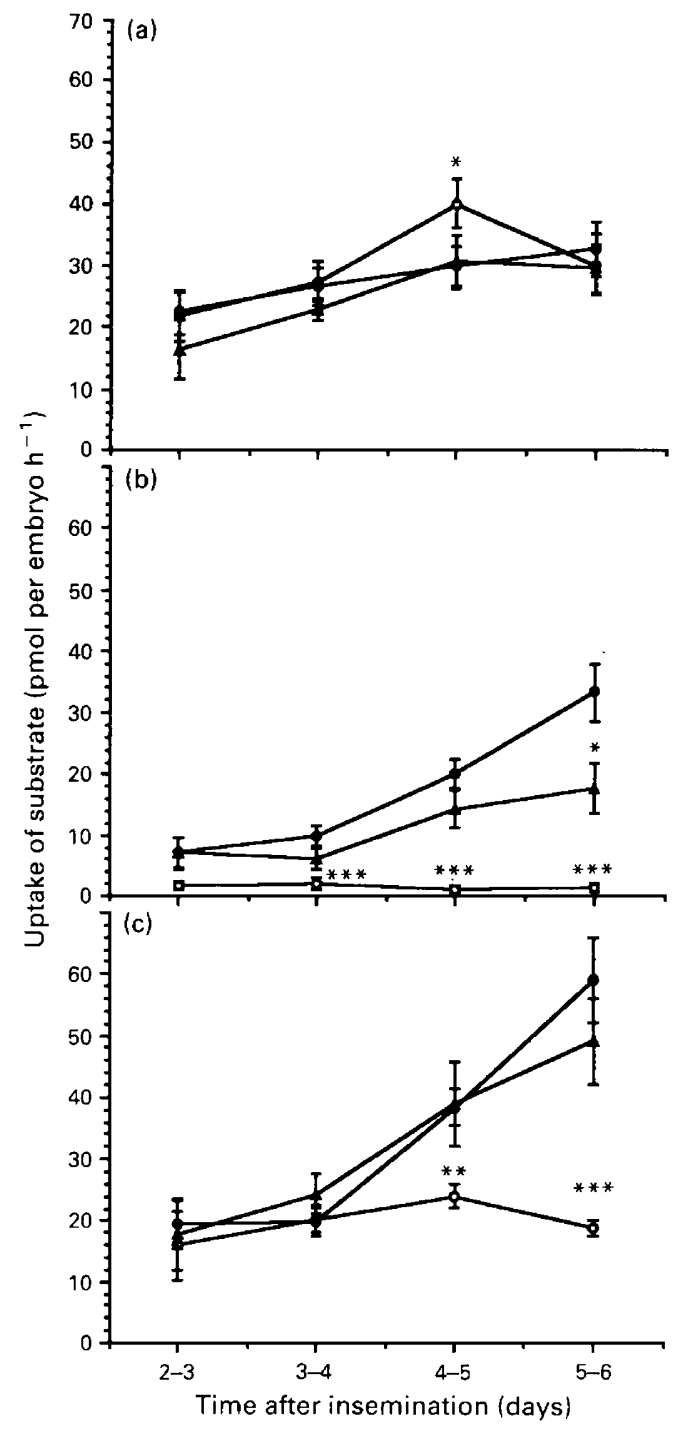

Fig. 3. Uptake of (a) pyruvate, (b) glucose and (c) production of lactate by embryos that reached the blastocyst stage in medium supplemented with (O) $0.0 \mathrm{mmol},(\boldsymbol{\Delta}) 0.5 \mathrm{mmol}$ and (O) $1.0 \mathrm{mmol}$ (control) glucose $\mathrm{I}^{-1}$. Pyruvate $\left(0.47 \mathrm{mmol}^{-1}\right)$ was present throughout. Values are means \pm SEM. Significantly different from control value $\left({ }^{*} P<0.05\right.$; $\left.{ }^{* *} P<0.01 ;{ }^{* *} P<0.001\right)$.

early stages of development, but significantly reduced in the absence of glucose at later stages, $P=0.008$ on day $4-5$ and $P=0.0003$ on day 5-6 when compared with control values (Fig. 3c). In the absence of glucose, an appreciable and consistent amount of lactate was formed on each day of the 4 day culture period.

\section{Discussion}

Up to $50 \%$ of human embryos develop successfully to the blastocyst stage (Hardy, 1993) and the time of arrest for the majority of embryos appears to be between the four- and eightcell stages (Bolton and Braude, 1987). If human embryos are to be grown more successfully in culture, it is important to consider their nutrient requirements. The patterns of uptake of several nutrients have been well documented over a number of years (Leese et al., 1986; Wales ef al., 1987; Hardy et al., 1989a; Gott et al., 1990b), but no significant changes in the formulations of culture media have resulted from these findings. If improvements are to be made in the number of embryos reaching at least the blastocyst stage, it may be necessary to design media around the interrelationships between the embryo and its environment, rather than supplying nutrients in excess.

We therefore exposed human preimplantation embryos to various concentrations of pyruvate and glucose and studied the effects on embryo metabolism and development, including number of blastocyst cells. Development of human embryos was found to be inhibited by glucose. We also demonstrated, for the first time, that pyruvate is essential for human preimplantation development, and that pyruvate alone will support development to the blastocyst stage. Finally, we examined the effects of substrate removal from the culture medium on embryo metabolism, as assessed by daily measurements of substrate uptake and lactate production. In control medium, the profiles of nutrient uptake and production, and the number of blastocyst cells, are similar to those reported previously from this laboratory (Hardy et al., 1989a,b; Gott et al., 1990b).

Pyruvate is a preferred substrate of preimplantation mouse (Leese and Barton, 1984) and human (Hardy et al., 1989a) embryos. Furthermore, pyruvate as sole energy substrate can support the development of a small proportion of hamster embryos to the blastocyst stage (Seshagiri and Bavister, 1989), and mouse embryos to the morula stage (Brown and Whittingham, 1991). Conversely, rabbit embryos will develop to the morula stage in the absence of exogenous substrate (Kane, 1987b). The present data show that complete removal of pyruvate from the medium has a detrimental effect on the number of human embryos reaching the blastocyst stage. Embryos could not compensate for low pyruvate concentrations by increasing their glucose uptake. Paradoxically, a significant fall in glucose uptake in pyruvate free medium was observed on day 4-5 of culture, when embryos were making the morula to blastocyst transition, indicating that there is a relationship between pyruvate and glucose uptake at this stage.

It was shown in the study reported here that lactate production is slightly increased during each daily culture period when pyruvate is present in the medium, and there are two possible explanations for this. First, some of the pyruvate taken up by the embryo may be converted to lactate, and where no pyruvate is available, less lactate appears in the medium. This is unlikely, however, as the amounts of lactate that are produced in media containing $0.47 \mathrm{mmol}$ and $0.23 \mathrm{mmol}$ pyruvate $\mathrm{l}^{-1}$ are similar at all stages of development. The second and most likely explanation for the increase in lactate production is that the development of the embryo is enhanced in the presence of pyruvate, and this is reflected in a general increase in metabolic activity, as demonstrated by more lactate production.

During early preimplantation development glucose uptake remains low in both mouse (Leese and Barton, 1984) and human embryos (Hardy et al., 1989a; Gott et al., 1990b). After activation of the embryonic genome, at the two-four-cell stage in mice (Flach et al., 1982) and the four-eight-cell stage in humans (Braude et al., 1988), there is a decline in pyruvate 
uptake in mice but not in humans (this study), and a surge in glucose uptake in both species (Leese and Barton, 1984; Gardner and Leese, 1986; Hardy et al., 1989a). These data suggest that glucose is not necessary during the early stages of development, and in the hamster embryo (Seshagiri and Bavister, 1989) and the mouse embryo (Chatot et al., 1989) removing glucose at various times during culture enhances embryo development. Adding glutamine and EDTA to the medium, and omitting glucose, overcame the two-cell block in the mouse embryo, but it was necessary to add glucose between the fourcell and morula stages to obtain reasonable numbers $(48 \%)$ of blastocysts (Chatot et al., 1989). Glucose was detrimental to embryo development during the first $48 \mathrm{~h}$ of culture, between the one-cell and three-four-cell stages.

The significant increase in the number of blastocyst cells caused by removing glucose from the medium $(99.1 \pm 13.5$ in glucose-free medium and $58.4 \pm 8.2$ in control medium; $P<0.02$ ) may be a result of an enhanced cleavage rate at earlier stages of embryo development. Slightly fewer embryos reached the eight-cell stage in control medium containing $1 \mathrm{mmol}$ glucose $1^{-1}$ than in medium containing $0.5 \mathrm{mmol}$ or

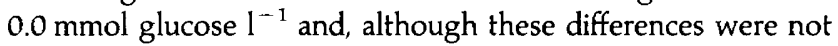
significant, it is likely that marginally improved development at this early stage may have contributed to the greater number of cells seen at the blastocyst stage. Reducing the glucose concentration in the medium enhanced embryo development to the eight-cell stage in mice (Chatot et al., 1989). Specifically, the rise in number of cells was most apparent in the trophectoderm, where numbers of cells was almost double in glucose-free medium $(66.1 \pm 7.7$ and $37.2 \pm 7.1$ in $0 \mathrm{mmol}$ and $1.0 \mathrm{mmol}$ glucose $1^{-1}$, respectively). Such a significant and dramatic rise in number of trophectoderm cells could improve the ability of blastocysts to implant after embryo transfer.

During culture in glucose-free medium a consistent and appreciable quantity of lactate was formed during each daily culture period in the study reported here. This provides evidence that embryos are obtaining energy from an endogenous source, and such an energy supply may have an important role in blastocyst formation. The four embryos that developed to the blastocyst stage in pyruvate-free medium all came from different patients and it may be that a small percentage of human embryos have sufficient endogenous energy to support development to the blastocyst stage without supplementation with exogenous nutrients. Endogenous energy supply could explain why blastocyst development rates are so variable among clinics using different superovulation protocols to generate oocytes.

The significant increase in pyruvate uptake on day $4-5$ in glucose free medium reported here is probably a result of the requirement for energy to bring about the transition from morula to blastocyst. The ability to compensate for a lack of glucose has been observed in mice (Gardner and Leese, 1988), but here it is not sustained since pyruvate uptake returned to control values by the following day (day 5-6). Glucose uptake is minimal for the first 2 days in culture, as described by Hardy et al. (1989a), before rising dramatically after the eight-cell stage on days $4-5$ and 5-6 (this study). Coupled with this rise in glucose uptake is an increase in the rate of glycolysis, shown here by an upsurge in lactate production. By the final culture period, when the embryos would have reached the blastocyst stage, glucose uptake is related to its concentration in the medium. This finding, together with the surge in glucose uptake observed by Hardy (1989a), suggests that the embryo depends on glucose at the blastocyst stage. In addition, glucose-free medium has been shown to delay blastocyst hatching in mice (Wordinger and Brinster, 1976), and could potentially cause the same problems with human embryos.

These results suggest that glucose is required at the later stages of preimplantation development and should be added back to the medium on about day 4 or 5 of development. This may further increase the capacity of human embryos to develop to the blastocyst stage, as is the case in mice with CZB medium (Chatot et al., 1989). Although a recent study, in which human embryos were cultured in CZB or Earle's medium, showed that blastocyst development was significantly greater $(50 \%)$ in $\mathrm{CZB}$ medium, development of control embryos in Earle's medium was low $(20 \%)$ (Fitzgerald and DiMattina, 1992). We have consistently observed a rate of blastocyst development approaching 50\% with Earle's (Dawson et al., 1988; Conaghan et al., 1993) and similar media (Hardy et al., 1989a, 1989b; Hardy, 1993), using culture conditions similar to those described by Fitzgerald and DiMattina (1992). These differences in rates of blastocyst development are puzzling, but may be due to different methods of superovulation or embryo handling or to both factors, possibly resulting in embryos with different endogenous energy stores. In addition, the media used in the experiment was supplemented with $10 \% \mathrm{v} / \mathrm{v}$ heat-inactivated human serum which not only negates the defined nature of the CZB medium but inevitably contains glucose. Furthermore, the time chosen to add glucose to the medium $(52 \mathrm{~h}$ after insemination) is peculiar as it is contradictory to the timing used in mice by Chatot et al. (1989), where glucose was added after the expected time of blocking (two-cell stage) and activation of the embryonic genome (between the two- and four-cell stage). Fitzgerald and DiMattina (1992) added glucose at about the mid-four-cell stage in humans, which is on or before both blocking and activation of the embryonic genome. Because of the reported low rates of blastocyst development in Earle's medium, the presence of human serum in the medium at all times, and the timing of glucose addition to the CZB medium, it is impossible to assess the value of CZB medium, for use with human embryos, based on these experiments. Nevertheless, all these data are consistent with the proposition that a succession of culture media, of differing composition, may be required for the optimal development of embryos to the blastocyst stage (Gardner and Leese, 1990; Leese, 1990; Brown and Whittingham, 1992).

In summary, human embryos have a preference for pyruvate over all preimplantation stages of development and its consumption is related to its concentration in the medium, at least for concentrations of $0.47 \mathrm{mmol} \mathrm{l}^{-1}$ and below. Fifty-nine per cent of embryos developed from the two-four-cell stage to the blastocyst stage in medium containing pyruvate as the sole energy source and omission of pyruvate from the culture medium resulted in a developmental arrest of $84 \%$ of the embryos. Of the concentrations used here, optimal blastocyst development occurred in medium containing $0.47 \mathrm{mmol}$ pyruvate $1^{-1}$. Removal of glucose from the medium slightly enhanced embryo development to the eight-cell stage and resulted in blastocysts with significantly more cells. Specifically, 
significantly more cells were found in the trophectoderm of blastocysts that were grown in glucose-free medium. However, human embryos displayed a marked rise in glucose consumption during the late preimplantation stages, after the time of activation of the embryonic genome and cleavage stage block, implying that glucose should be present in the medium at the later stages of development. Thus inhibition by glucose is likely to affect only early cleavage stages, including human embryos before transfer following IVF. This study has provided strong evidence to indicate that optimal human embryo development occurs in glucose-free medium, especially at early cleavage stages before and after embryo transfer.

The authors would like to thank K. Hardy for helpful discussions on the work, for suggestions on the experimental design and useful comments on the manuscript. They also thank K. Dawson and the IVF team at Hammersmith hospital for their help, encouragement and support. Finally, this work would not have been possible without awards from the Medical Research Council to H. J. Leese and R. M. L. Winston.

\section{References}

Biggers JD (1971) New observations on the nutrition of the mammalian oocyte and the preimplantation embryo. In The Biology of the Blastocyst pp 319-327 Ed. RJ Blandau. University of Chicago Press, Chicago

Bolton VN and Braude PR (1987) Development of the human preimplantation embryo in vitro Current Topics in Developmental Biology 23 93-114

Bolton VN, Hawes SM, Taylor CT and Parsons JH (1989) Development of spare human preimplantation embryos in vitro: an analysis of the correlations among gross morphology, cleavage rates and development to the blastocyst Journal of In Vitro Fertilisation and Embryo Transfer 6 30-35

Braude P, Bolton V and Moore S (1988) Human gene expression first occurs between the four- and eight-cell stages of preimplantation development Nature 332 459-461

Brison DR and Leese HJ (1991) Energy metabolism in late preimplantation rat embryos Journal of Reproduction and Fertility 93 243-251

Brown JJG and Whittingham DG (1991) The roles of pyruvate, lactate and glucose during preimplantation development of embryos from $F_{1}$ hybrid mice in vitro Development 112 99-105

Brown JIG and Whittingham DG (1992) The dynamic provision of different energy substrates improves development of one-cell random-bred mouse embryos in vitro Journal of Reproduction and Fertility 95 503-511

Chatot CL, Ziomek CA, Bavister BD, Lewis JL and Torres I (1989) An improved culture medium supports development of random-bred I-cell mouse embryos in vitro Journal of Reproduction and Fertility 86 679-688

Chatot CL, Lewis JL, Torres I and Ziomek CA (1990) Development of I-cell embryos from different strains of mice in CZB medium Biology of Reproduction $42432-440$

Conaghan J, Martin K, Hardy K, Winston NJ, Dawson KJ, Winston RML and Leese HJ (1991) Can non-invasive measurement of pyruvate uptake in culture assist embryo selection for transfer following in-vitro fertilization Joumal of Obstetrics and Gynaecology 11 87-88

Conaghan J, Hardy K, Handyside AH, Winston RML and Leese HJ (1993) Selection criteria for human embryo transfer: a comparison of pyruvate uptake and morphology Journal of Assisted Repraduction and Genetics 10 $21-30$

Dawson K, Margara RA, Hillier SG, Packham D, Winston N and Winston RML (1987) Factors affecting success at the time of embryo transfer Human Reproduction Abstracts from the third meeting of ESHRE. Abstract 134

Dawson K, Rutherford AJ, Winston NJ, Subak-Sharpe R and Winston RML (1988) Human blastocyst transfer, is it a feasible proposition? Human Reproduction Abstracts from the fourth meeting of ESHRE. Abstract 145

De Hertogh R, Vanderheyden I, Pampfer S, Robin D, Dufrasne E and Delcourt J (1991) Stimulatory and inhibitory effects of glucose and insulin on rat blastocyst development in vitro Diabetes 40 641-647
Dorland M, Kruip TAM and van der Donk JA (1992) Assessing day 7 bovine embryo viability by measuring the rate of nutrient uptake Joumal of Reproduction and Fertility Abstract Series 9 Abstract 40

FitzGerald L and DiMattina M (1992) An improved medium for long-term culture of human embryos overcomes the in vitro developmental block and increases blastocyst formation Fertility and Sterility 57 641-647

Flach G, Johnson MH, Braude PR, Taylor RAS and Bolton VN (1982) The transition from maternal to embryonic control of preimplantation mouse development EMBO Journal 1 681-686

Gardner DK and Leese HJ (1986) Non-invasive measurement of nutrient uptake by single cultured preimplantation mouse embryos Human Reproduction $\mathbf{1}$ $25-27$

Gardner DK and Leese HJ (1988) The role of glucose and pyruvate transport in regulating nutrient utilization by preimplantation mouse embryos Development 104 423-429

Gardner DK and Leese HJ (1990) Concentrations of nutrients in mouse oviduct fluid and their effects on embryo development and metabolism in vitro Journal of Reproduction and Fertility 88 361-368

Gott AL, Hardy K, Winston RML and Leese HJ (1990a) The nutrition and environment of the early human embryo Proceedings of the Nutrition Society 42 2a

Gott AL, Hardy K, Winston RML and Leese HJ (1990b) Non-invasive measurement of pyruvate and glucose uptake and lactate production by single human preimplantation embryos Human Reproduction 5 104-108

Hagen DR, Prather RS, Sims MM and First NL (1991) Development of one-cell porcine embryos to the blastocyst stage in simple media journal of Animal Science 69 1147-1150

Handyside AH and Hunter S (1984) A rapid procedure for visualising the inner cell mass and trophectoderm nuclei of mouse blastocysts in situ using polynucleotide-specific fluorochromes Joumal of Experimental Zoology 231 429-434

Handyside AH and Hunter S (1986) Cell division and death in the mouse blastocyst before implantation Roux's Archives of Developmental Biology 195 519-526

Hardy K (1993) Development of human blastocysts in vitro. In Preimplantation Embryo Development pp 184-199 Ed. B Bavister. Springer-Verlag, New York

Hardy K, Hooper MAK, Handyside AH, Rutherford AJ, Winston RML and Leese HJ (1989a) Non-invasive measurement of glucose and pyruvate uptake by individual human oocytes and preimplantation embryos Human Reproduction 4 I88-191

Hardy K, Handyside AH and Winston RML (1989b) The human blastocyst: cell number, death and allocation during late preimplantation development in vitro Development $107597-604$

Harrison J, Hodson AW, Skillen AW, Stappenbeck R, Agius L and Alberti KGMM (1988) Blood glucose, lactate, pyruvate, glycerol, 3-hydroxybutyrate and acetoacetate measurements in man using a centrifugal analyser with a fluorimetric attachment Journal of Clinical Chemistry and Clinical Biochemistry $26141-146$

Hillier SG, Dawson KJ, Afnan M, Margara RA, Ryder TA, Wickings EJ and Winston RML (1984) Embryo culture: quality control in in vitro fertilization. In Proceedings of the Twelfth Study Group of the Royal College of Obstetricians and Gynaecologists pp 125-140 Eds W Thompson, DN Joyce and JR Newton. Royal College of Obstetricians and Gynaecologists, London

Hillier SG, Afnan AMM, Margara RA and Winston RML (1985) Superovulation strategy before in vitro fertilization Clinical Obstetrics and Gynaecology 12 $687-723$

Kane MT (1987a) Minimal nutrient requirements for culture of one-cell rabbit embryos Biology of Reproduction 37 775-778

Kane MT (1987b) In vitro growth of preimplantation rabbit embryos. In The Mammalian Preimplantation Embryo. Regulation of Growth and Differentiation in vitro pp 193-217 Ed. BD Bavister. Plenum Press, New York

Lawitts JA and Biggers JD (1991) Optimization of mouse embryo culture media using simplex methods Journal of Reproduction and Fertility 91 543-556

Leese HJ (1990) The environment of the preimplantation embryo. In Establishing a Successful Human Pregnancy pp 143-154 Ed. RG Edwards, Serono Symposia Vol 66. Raven Press, New York

Leese HJ (1991) Metabolism of the preimplantation mammalian embryo Oxford Reviews of Reproductive Biology 13 35-72

Leese $\mathrm{HJ}$ and Barton AM (1984) Pyruvate and glucose uptake by mouse ova and preimplantation embryos Joumal of Reproduction and Fertility 72 9-13

Leese HJ and Lenton EA (1990) Glucose and lactate in human follicular fluid: concentrations and interrelationships Human Reproduction 5 915-919 
Leese HJ, Hooper MAK, Edwards RG and Ashwood-Smith MJ (1986) Uptake of pyruvate by early human embryos determined by a non-invasive technique Human Reproduction 1 181-182

Leese HJ, Conaghan JC, Martin KL and Hardy K (1993) Early human embryo metabolism Bioessays 15 259-264

McKiernan SH, Bavister BD and Tasca RJ (1991) Energy substrate requirements for in vitro development of hamster 1 - and 2-cell embryos to the blastocyst stage Human Reproduction 6 64-75

Petters RM, Johnson BH, Reed ML and Archibong AE (1990) Glucose, glutamine and inorganic phosphate in early development of the pig embryo in vitro Joumal of Reproduction and Fertility 89 269-275

Plachot M, Mandelbaum J, Junca AM, de Grouchy J, Cohen J, Salat-Baroux J and Da Lage C (1986) Morphologic, cytologic and cytogenetic studies of human embryos obtained by IVF. In In vitro Fertilisation (Proceedings of the 12th World Congress on Fertility and Sterility) Vol 2 pp 61-65 Eds SS Ratnam and ES Teon. Parthenon Publishing Group, Lancs

Reed ML, Jin DI and Petters RM (1992) Glucose and inorganic phosphate inhibits rat 8-cell embryo development in vitro Theriogenology 37282

Rieger D, Loskutoff NM and Betteridge KJ (1992) Developmentally related changes in the metabolism of glucose and glutamine by cattle embryos produced and co-cultured in vitro Journal of Reproduction and Fertility 95 $585-595$

Robinson DH and Benos DJ (1991) Glucose metabolism in the trophectoderm and inner cell mass of the rabbit embryo Journal of Reproduction and Fertility 91 493-499

Rutherford AJ, Subak-Sharpe R, Dawson K, Margara RA, Franks S and Winston RML (1988) Dramatic improvement in IVF success following treatment with LHRH agonist British Medical Journal 296 1765-1768
Schini SA and Bavister BD (1988) Two-cell block to development of cultured hamster embryos is caused by phosphate and glucose Biology of Reproduction 39 1183-1192

Scott RT, Hofmann GE, Veeck LL, Jones HW and Muasher SJ (1991) Embryo quality and pregnancy rates in patients attempting pregnancy through in vitro fertilization Fertility and Sterility $\mathbf{5 5}$ 426-428

Seshagiri PB and Bavister BD (1989) Glucose inhibits development of hamster 8-cell embryos in vitro Biology of Reproduction 40 599-606

Stappenbeck R, Hodson AW, Skillen AW, Agius L and Alberti KGMM (1990) Optimized methods to measure acetoacetate, 3-hydroxybutyrate, glycerol, alanine, pyruvate, lactate and glucose in human blood using a centrifugal analyser with a fluorimetric attachment Joumal of Automatic Chemistry 12 213-220

Thompson JGE, Simpson AC, Pugh PA, Wright RW and Tervit HR (1991) Glucose utilization by sheep embryos derived in vivo and in vitro Reproduction Fertility and Development 3 571-576

Thompson JG, Simpson AC, Pugh PA and Tervit HR (1992) Requirement for glucose during in vitro culture of sheep preimplantation embryos Molecular Reproduction and Development 31 253-257

Wales RG, Whittingham DG, Hardy K and Craft IL (1987) Metabolism of glucose by human embryos Journal of Reproduction and Fertility 79 289-297

Wordinger RJ and Brinster RL (1976) Influence of reduced glucose levels on the in vitro hatching, attachment, and trophoblast outgrowth of the mouse blastocyst Developmental Biology 53 294-296

Zhang $X$ and Armstrong DT (1990) Presence of amino acids and insulin in a chemically defined medium improves development of 8-cell rat embryos in vitro and subsequent implantation in vivo Biology of Reproduction $\mathbf{4 2}$ $662-668$ 